\title{
Research Square \\ Influence of childcare attendance on the development of two-year-olds in a Brazilian birth cohort study
}

Otávio Amaral de Andrade Leão ( $\boldsymbol{Q}$ otavioaaleao@gmail.com )

Universidade Federal de Pelotas https://orcid.org/0000-0002-5253-7665

Mariângela Freitas da Silveira

Universidade Federal de Pelotas

Marlos Rodrigues Domingues

Universidade Federal de Pelotas

Joseph Murray

Universidade Federal de Pelotas

Nelson Arns Neumann

National Coordination of the Pastoral da Criança

Caroline Caus Dalabona

National Coordination of the Pastoral da Criança

Gregore Iven Mielke

Central Queensland University

Andréa Homsi Dâmaso

Universidade Federal de Pelotas

Research article

Keywords: Child development, Childcare, Infant, Brazil, Cohort Studies, Epidemiology, Public health

Posted Date: January 16th, 2020

DOI: https://doi.org/10.21203/rs.2.20991/v1

License: (c) (1) This work is licensed under a Creative Commons Attribution 4.0 International License. Read Full License 


\section{Abstract}

Background: The first years of life are the most important for human development, which is influenced by diverse factors, such as childcare attendance. Yet, little is known about the longitudinal influence of childcare in diverse domains of development. The aim of the present study was to assess the development and to measure potential influences of childcare attendance in two-year-olds from the 2015 Pelotas (Brazil) Birth Cohort Study.

Methods: The present study used longitudinal data from the 2015 Pelotas Birth Cohort. Childhood development at two-year-olds was assessed throughout INTER-NDA (INTERGROWTH-21st Neurodevelopment Assessment). Childcare attendance was measured at ages 1 and 2 years old and categorized as: a) never went to childcare; b) attended some childcare (either at 12 or 24 months); c) always attended childcare (both 12 and 24 months). Demographic, socioeconomic, health, and child stimulation variables were considered as confounders. Crude and adjusted analysis of childcare attendance and early childhood development were performed using linear regression.

Results: Among the 3,870 infants included in the analyses, around 2/3 never went to childcare. In the crude analyses, any exposure to childcare was positively associated with development, except for in the motor domain. It was also perceived a trend positive association and higher mean values for the always category. In the adjusted analyses only children who always went to childcare had higher development scores in the total $(\beta: 0.17,95 \% \mathrm{Cl}: 0.06 ; 0.28)$, cognitive $(\beta: 0.10,95 \% \mathrm{Cl}:-0.003 ; 0.21)$ and language $(\beta: 0.10,95 \% \mathrm{Cl}:-0.003 ; 0.21)$ domains, even after adjustment for stimulation variables.

Conclusions: This study suggests that childcare may help improve early childhood development. The association was particularly strong for the total global development domain, even after adjusting for stimulation, but there was no association with motor development. Considering the low prevalence of children in childcare, and that it may support child development it is recommended to improve childcare opportunities in early childhood.

\section{Background}

The most important period for growth and development are the first years of life, which have a major impact on future health (1). Child development is an interactive and maturational process, with the environment affecting multiple domains of development, including motor, language, cognitive, socioemotional and self-regulation skills (2).

Recent evidence suggest that, in low and middle income countries, about 80 million children at ages 3 and 4 years, experienced low cognitive and/or socio-emotional development in 2010 (3). A more recent study, including data from over 330,000 children from 63 low and middle-income countries, found that a quarter of the children were suspected to have developmental delay (4). Thus, strategies to promote adequate development such as nurturing care, physical health, adequate early learning opportunities, and security and safety are critical in these countries (5). 
A large body of work has considered how childcare environments can influence developmental outcomes. A review showed that most early education and care programs, based on care centers, had positive shortterm effects and small positive long-term effects on cognitive development (6). Yet, the literature in low and middle-income countries is scarce, especially considering a longitudinal and/or dose-response of the childcare in the infant development.

Considering the 4th Goal of the Sustainable Development Goals, which include: "by 2030, ensure that all girls and boys have access to quality early childhood development, care and preprimary education so that they are ready for primary education" (7), it is important to understand the role of childcare for early child development (ECD), especially in middle-income countries. The aim of this study was to investigate the association between childcare attendance from birth to 2 years and development at 2 years in a large population based cohort study in Brazil.

\section{Methods}

\section{Study design and population}

We analyzed data from the 2015 Pelotas (Brazil) Birth Cohort Study. Pelotas is a city in southern Brazil, with around 340,000 inhabitants. All hospital-delivered children live born in Pelotas between 1 January and 31 December 2015, whose mother lived in the urban area of the city, were eligible for the study (8). From the 4,333 eligible live births, 4,275 were assessed at birth (response rate $98.7 \%$ ). All these children and their mothers were invited to follow-up measures at 3,12 and 24 months. Further information about the 2015 Pelotas Birth Cohort is available elsewhere $(8,9)$.

\section{2 years follow-up}

In the 2 years follow-up, the interviews were conducted at a research clinic, with a follow-up rate of $95.4 \%$. Mothers answered a questionnaire (updating previous information about the child's and mother's health, household characteristics, diseases, child activities, among other topics). All procedures were done by female interviewers trained and retrained during the data collection phase. Written informed consent was obtained for participation in all phases of the study. The 2015 Pelotas birth cohort study was approved by the Research Ethics Committee of the School of Physical Education of Federal University of Pelotas (registration no. 26746414.5.0000.5313).

\section{Infant development}

Infant development was assessed when children were between 21-27 months old using the INTER-NDA (INTERGROWTH-21st Neurodevelopment Assessment) (10). It consists of 53 items that are directly administered, concurrently observed and caregiver reported. INTER-NDA was designed to be free from cultural biases and is based upon objective reporting of the child's performance on cognition, expressive 
and receptive language, gross and fine motor skills, behavior, attention and social-emotional reactivity. This instrument presents Interclass coefficient ranges between 0.75 and $0.83(p<0.001)$ and a moderate agreement with the Bayley Scales of Infant Development III ( $k=0.72, p<0.001)$, a well-established child development assessment, measuring cognition, language skills, motor skills and adaptive behavior from 1 to 42 months. The validation tests were perfomed in Oxford, United Kingdom, with eighty-one children aged 23-28 months old (11).

Assessment of children who did not present any serious physical or neural disability precluding them doing the INTER-NDA assessment was conducted by trained interviewers, not experts in neurodevelopment, when children went to the clinic (excluding the phone interviews), or in the family's home. Age-adjusted scores were calculated for cognition, receptive language, motor domains and global development (mean of the domains combined). The adjustment considers a mean of 0 and a standard deviation of 1 .

\section{Childcare attendance}

Childcare outside the home was measured using interview data from the 1 and 2-year follow-ups. In the 1 year follow-up, mothers were asked about who took care of their children from birth to 1 year, and children receiving any external childcare in that period were identified. At 2 years, mothers reported whether children were currently attending external childcare. Those who responded "no", were also asked if the child attended any external childcare since 1 year, although they were not currently in childcare.

For our analyses, childcare attendance reported at ages 1 and 2 years was categorized in three mutually exclusive categories as: a) never went to childcare; b) attended some childcare (either at 1 or at 2 years only); c) always (both 1 and 2 years).

\section{Confounders}

Covariates measured in the perinatal interview in this study were: sex (female/male), maternal age ( $\leq 20$, 21-30 and $\geq 31$ ), family income (quintiles), maternal education (0-4, 5-8, 9-11 and $12+$ years of schooling), pre-term (<37 weeks), low birth weight $(<2500 \mathrm{~g})$. Additionally, maternal depression was measured using the Edinburgh Postnatal Depression Scale (EPDS) (12), at the 3-month follow-up, with a cut-off point of $\geq 13$ points to indicate the presence of at least moderate depression (13).

In the 2-years follow-up, mothers were asked if they read or told stories to their child (yes/no), if the child visited the house of other people in the past week (yes/no), went to the park or some square in the last week (yes/no), and also if the child participated in the PIM (Primeira Infância Melhor) programme, a government home visitation programme that aims to enhance ECD in vulnerable households with young children. 


\section{Statistical analysis}

The analyses were conducted using Stata 16.0 in five steps: (a) descriptive analyses of children and their mothers were conducted for the entire cohort and compared with those with valid outcome data; (b) description of the participants, according to childcare attendance; (c) description of the participants according to child development; (d) crude analysis of the relationship between the outcomes and childcare attendance; (e) adjusted analysis of the relationship between the outcomes and childcare attendance.

For the first two stages ( $a$ and b), chi-squared tests were used. In steps c, $d$ and e, linear regression models were used. For step e, adjusted analyses were conducted including all covariates at the same time as model I. Model II also included variables related to ECD stimulation. Statistical significance was set at $5 \%$, and $95 \%$ confidence intervals are provided.

\section{Results}

Of the 4,275 children from the original cohort, 3,870 had developmental data at age 2 years and were included in the analyses. Their mothers were mostly $21-30$ years old, had 9-11 years of education and about $10 \%$ presented depression symptoms. In addition, about $15 \%$ of the children were born pre-term and $10 \%$ were low birth weight. Half of the children were stimulated through storytelling by their parents, almost $60 \%$ went to park or square, more than $4 / 5$ went to other people houses and about $10 \%$ participate in PIM program, in the 2 yearsfollow-up (Table 1). 
Table 1

Descriptive characteristics of the study sample and Pelotas birth cohort sample.

\begin{tabular}{|c|c|c|}
\hline & $\begin{array}{l}\text { Cohort characteristics } \\
(\mathrm{N}=4,275)\end{array}$ & $\begin{array}{l}\text { Inter NDA Sample } \\
(\mathrm{N}=3,870)\end{array}$ \\
\hline Characteristics & $\mathrm{N}(\%)$ & $\mathrm{N}(\%)$ \\
\hline \multicolumn{3}{|l|}{ Sex } \\
\hline Male & $2164(50.6)$ & $1965(50.8)$ \\
\hline Female & $2111(49.4)$ & $1905(49.2)$ \\
\hline \multicolumn{3}{|c|}{ Mother's age at birth* } \\
\hline$\leq 20$ & $805(18.8)$ & $719(18.5)$ \\
\hline $21-30$ & $2067(48.4)$ & $1883(48.7)$ \\
\hline$\geq 31$ & $1402(32.8)$ & $1268(32.8)$ \\
\hline \multicolumn{3}{|c|}{ Income (quintiles) } \\
\hline 1 (Low) & $796(19.8)$ & $716(19.6)$ \\
\hline 2 & $807(20.1)$ & $732(20.1)$ \\
\hline 3 & $804(20.0)$ & $741(20.3)$ \\
\hline 4 & $895(22.3)$ & $820(22.5)$ \\
\hline 5 (High) & $714(17.8)$ & $636(17.5)$ \\
\hline \multicolumn{3}{|c|}{ Mother's education } \\
\hline $0-4$ & $391(9.2)$ & $342(8.9)$ \\
\hline $5-8$ & $1095(25.6)$ & $1003(25.9)$ \\
\hline $9-11$ & $1458(34.1)$ & $1344(34.7)$ \\
\hline $12+$ & $1330(31.1)$ & $1180(30.5)$ \\
\hline \multicolumn{3}{|c|}{ Pre term (<37 weeks) } \\
\hline Yes & $663(15.5)$ & $570(14.7)$ \\
\hline No & $3612(84.5)$ & $3300(85.3)$ \\
\hline \multicolumn{3}{|c|}{ Low birth weight $(<2500 \mathrm{~g})$} \\
\hline No & $3830(89.9)$ & $3497(90.4)$ \\
\hline
\end{tabular}

* Highest number of missing for income $(\mathrm{N}=3645)$ 


\begin{tabular}{|c|c|c|}
\hline & $\begin{array}{l}\text { Cohort characteristics } \\
(\mathrm{N}=4,275)\end{array}$ & $\begin{array}{l}\text { Inter NDA Sample } \\
(\mathrm{N}=3,870)\end{array}$ \\
\hline Yes & $428(10.1)$ & $371(9.6)$ \\
\hline \multicolumn{3}{|c|}{ Mother's depression (3 m) } \\
\hline No & $3642(88.9)$ & $3395(89.0)$ \\
\hline Yes & $453(11.1)$ & $420(11.0)$ \\
\hline \multicolumn{3}{|c|}{ Parents storytelling (2y) } \\
\hline No & $1912(47.7)$ & $1851(47.9)$ \\
\hline Yes & $2099(52.3)$ & $2016(52.1)$ \\
\hline \multicolumn{3}{|c|}{ Child went to park or square (2y) } \\
\hline No & $1678(41.8)$ & $1629(42.1)$ \\
\hline Yes & $2333(58.2)$ & $2238(57.9)$ \\
\hline \multicolumn{3}{|c|}{ Child went to other people house (2y) } \\
\hline No & $638(15.9)$ & $592(15.3)$ \\
\hline Yes & $3373(84.1)$ & $3275(84.7)$ \\
\hline \multicolumn{3}{|c|}{ Participation in PIM (2y) } \\
\hline No & $3637(90.7)$ & $3500(90.5)$ \\
\hline Yes & $374(9.3)$ & $367(9.5)$ \\
\hline
\end{tabular}

Table 2 indicates that boys, children with low birth weight, mothers tended to be older, richer, more educated and with no depression symptoms, were the ones who attended more external childcare. In addition, children who were stimulated through storytelling, taken to park or square and did not participate in the PIM attended more in external childcare. 
Table 2

Prevalence of childcare according to sample characteristics $(\mathrm{N}=3870)$

\begin{tabular}{|c|c|c|c|c|}
\hline & Childcare at & ndance & & \\
\hline Characteristics & Never & Some & Always & $\mathrm{p}$-Value \\
\hline Sex & & & & 0.034 \\
\hline Male & $1256(65.1)$ & $453(23.5)$ & $219(11.4)$ & \\
\hline Female & $1275(68.9)$ & $400(21.6)$ & $175(9.5)$ & \\
\hline Mother's age & & & & $<0.001$ \\
\hline$\leq 20$ & $542(77.0)$ & $130(18.5)$ & $32(4.5)$ & \\
\hline $21-30$ & $1244(67.7)$ & $402(21.9)$ & $192(10.4)$ & \\
\hline$\geq 31$ & $745(60.3)$ & $321(26.0)$ & $170(13.7)$ & \\
\hline Income & & & & $<0.001$ \\
\hline 1 (low) & $559(80.3)$ & $110(15.8)$ & $27(3.9)$ & \\
\hline 2 & $559(78.5)$ & $116(16.3)$ & $37(5.2)$ & \\
\hline 3 & $477(65.5)$ & $169(23.2)$ & $82(11.3)$ & \\
\hline 4 & $461(57.0)$ & $222(27.4)$ & $126(15.6)$ & \\
\hline 5 (high) & $321(51.9)$ & $192(31.1)$ & $105(17.0)$ & \\
\hline Mother's education & & & & $<0.001$ \\
\hline $0-4$ & $289(87.3)$ & $34(10.3)$ & $8(2.4)$ & \\
\hline $5-8$ & $786(81.3)$ & $147(15.2)$ & $34(3.5)$ & \\
\hline $9-11$ & $898(67.5)$ & $306(23.0)$ & $127(9.5)$ & \\
\hline $12+$ & $557(48.5)$ & $366(31.9)$ & $225(19.6)$ & \\
\hline Pre term (<37 weeks) & & & & 0.052 \\
\hline Yes & $395(70.8)$ & $119(21.3)$ & $44(7.9)$ & \\
\hline No & $2136(66.3)$ & $734(22.8)$ & $350(10.8)$ & \\
\hline Low birth weight $(<2500 \mathrm{~g})$ & & & & 0.036 \\
\hline No & $257(71.6)$ & $78(21.8)$ & $24(6.7)$ & \\
\hline Yes & $2273(66.5)$ & $775(22.7)$ & $369(10.8)$ & \\
\hline Mother's depression (3 m) & & & & 0.003 \\
\hline
\end{tabular}




\begin{tabular}{|lllll|}
\hline \multicolumn{5}{|c|}{ Childcare attendance } \\
\hline No & $2205(66.1)$ & $769(23.1)$ & $362(10.8)$ & \\
\hline Yes & $305(74.6)$ & $72(17.6)$ & $32(7.8)$ & \\
\hline Parents storytelling (2y) & & & & $<0.001$ \\
\hline No & $1393(77.2)$ & $290(16.1)$ & $121(6.7)$ & \\
\hline Yes & $1138(57.7)$ & $563(28.5)$ & $273(13.8)$ & \\
\hline Child went to park or square (2y) & & & & $<0.001$ \\
\hline No & $1186(74.5)$ & $286(17.9)$ & $121(7.6)$ & \\
\hline Yes & $1345(61.6)$ & $567(25.9)$ & $273(12.5)$ & \\
\hline Child went to other people house (2y) & & & & 0.34 \\
\hline No & $393(68.5)$ & $131(22.8)$ & $50(8.7)$ & \\
\hline Yes & $2138(66.7)$ & $722(22.5)$ & $34(10.8)$ & \\
\hline Participation in PIM (2y) & & & & $<0.001$ \\
\hline No & $2227(65.2)$ & $804(23.5)$ & $386(11.3)$ & \\
\hline Yes & $304(84.2)$ & $49(13.6)$ & $8(2.2)$ & \\
\hline
\end{tabular}

Table 3 shows that boys presented a smaller mean of total, cognitive and language measures. Children of mothers older than 30 presented a lower mean of total development score compared to children of younger mothers. Income and maternal education presented a positive relationship with the outcomes, in which sons of richer and more educated mothers presented higher scores of development except for the motor domain. Mother's depression symptoms presented a negative relationship with cognitive and language domains. Children born pre-term and with low birth weight presented lower means in the four outcomes. Children, whose parents read stories, take them to the park and to other people houses presented higher means in all outcomes, except motor in the ones who went to the park. Participation in PIM was negatively associated with cognitive and language domains. 
Table 3

Association between early childhood development at 2 years and sample characteristics $(N=3870)$.

DEVELOPMENT

\begin{tabular}{|c|c|c|c|c|}
\hline Characteristics & TOTAL & COGNITIVE & MOTOR & LANGUAGE \\
\hline \multicolumn{5}{|l|}{ Sex } \\
\hline Male & $\begin{array}{l}-0.19(-0.25 \\
-0.13)\end{array}$ & $\begin{array}{l}-0.29(-0.36 \\
-0.23)\end{array}$ & $\begin{array}{l}0.03(-0.03 \\
0.09)\end{array}$ & $\begin{array}{l}-0.30(-0.36 \\
-0.24)\end{array}$ \\
\hline Female & 0 & 0 & 0 & 0 \\
\hline \multicolumn{5}{|l|}{ Mother's age } \\
\hline$\leq 20$ & 0 & 0 & 0 & 0 \\
\hline $21-30$ & $\begin{array}{l}-0.07(-0.16 \\
0.1)\end{array}$ & $\begin{array}{l}0.01(-0.07 ; \\
0.10)\end{array}$ & $\begin{array}{l}-0.01(-0.10 ; \\
0.07)\end{array}$ & $\begin{array}{l}0.01(-0.08 ; \\
0.09)\end{array}$ \\
\hline$\geq 31$ & $\begin{array}{l}-0.15(-0.24 ; \\
-0.05)\end{array}$ & $\begin{array}{l}-0.02(-0.11 ; \\
0.07)\end{array}$ & $\begin{array}{l}-0.06(-0.15 \\
0.03)\end{array}$ & $\begin{array}{l}-0.03(-0.12 ; \\
0.06)\end{array}$ \\
\hline \multicolumn{5}{|l|}{ Income } \\
\hline 1 (low) & 0 & 0 & 0 & 0 \\
\hline 2 & $\begin{array}{l}-0.03(-0.13 ; \\
0.07)\end{array}$ & $\begin{array}{l}0.03(-0.07 \\
0.14)\end{array}$ & $\begin{array}{l}-0.03(-0.13 ; \\
0.08)\end{array}$ & $\begin{array}{l}0.04(-0.06 \\
0.14)\end{array}$ \\
\hline 3 & $\begin{array}{l}0.06(-0.03 \\
0.17)\end{array}$ & $\begin{array}{l}0.15(0.05 \\
0.25)\end{array}$ & $\begin{array}{l}0.04(-0.06 \\
0.15)\end{array}$ & $\begin{array}{l}0.14(0.04 ; \\
0.24)\end{array}$ \\
\hline 4 & $\begin{array}{l}0.09(-0.01 \\
0.19)\end{array}$ & $\begin{array}{l}0.21(0.11 \\
0.31)\end{array}$ & $\begin{array}{l}0.06(-0.04 \\
0.16)\end{array}$ & $\begin{array}{l}0.21(0.11 \\
0.31)\end{array}$ \\
\hline 5 (high) & $\begin{array}{l}0.17(0.07 ; \\
0.28)\end{array}$ & $\begin{array}{l}0.37(0.26 \\
0.48)\end{array}$ & $\begin{array}{l}0.06(-0.04 \\
0.17)\end{array}$ & $\begin{array}{l}0.37(0.26 \\
0.47)\end{array}$ \\
\hline
\end{tabular}

Mother's education

\begin{tabular}{lllll}
$0-4$ & 0 & 0 & 0 & 0 \\
$5-8$ & $0.09(-0.03 ;$ & $0.19(0.06 ;$ & $0.10(-0.02 ;$ & $0.18(0.06 ;$ \\
& $0.21)$ & $0.31)$ & $0.22)$ & $0.30)$ \\
\hline $9-11$ & $0.12(-0.01 ;$ & $0.29(0.17 ;$ & $0.08(-0.04 ;$ & $0.28(0.17 ;$ \\
& $0.24)$ & $0.41)$ & $0.20)$ & $0.40)$ \\
$12+$ & $0.20(0.08 ;$ & $0.49(0.37 ;$ & $0.11(-0.01 ;$ & $0.48(0.36 ;$ \\
& $0.33)$ & $0.61)$ & $0.23)$ & $0.60)$
\end{tabular}

Pre term $(<37$ weeks $)$ 


\section{DEVELOPMENT}

\begin{tabular}{lllll} 
Yes & 0 & 0 & 0 & 0 \\
\hline No & $0.24(0.15 ;$ & $0.28(0.20 ;$ & $0.15(0.06 ;$ & $0.28(0.19 ;$ \\
& $0.33)$ & $0.37)$ & $0.24)$ & $0.37)$
\end{tabular}

Low birth weight $(<2500 \mathrm{~g})$

$\begin{array}{lllll}\text { No } & 0 & 0 & 0 & 0 \\ \text { Yes } & -0.19(-0.29 ; & -0.26(-0.37 ; & -0.13(-0.24 ; & -0.25(-0.36 ; \\ & -0.08) & -0.15) & -0.03) & -0.15)\end{array}$

Mother's depression (3 m)

$\begin{array}{lllll}\text { No } & 0 & 0 & 0 & 0 \\ \text { Yes } & 0.06(-0.04 ; & -0.17(-0.27 ; & -0.05(-0.15 ; & -0.17(-0.27 ; \\ & 0.16) & -0.07) & 0.05) & -0.07)\end{array}$

Parents storytelling

$\begin{array}{lllll}\text { No } & 0 & 0 & 0 & 0 \\ \text { Yes } & 0.10(0.04 ; & 0.26(0.20 ; & 0.10(0.04 ; & 0.27(0.20 ; \\ & 0.17) & 0.32) & 0.17) & 0.33)\end{array}$

Child went to park or square $(2 \mathrm{y})$

$\begin{array}{lllll}\text { No } & 0 & 0 & 0 & 0 \\ \text { Yes } & 0.08(0.02 ; & 0.12(0.05 ; & 0.01(-0.05 ; & 0.12(0.05 ; \\ & 0.15) & 0.18) & 0.07) & 0.18)\end{array}$

Child went to other people house (2y)

$\begin{array}{lllll}\text { No } & 0 & 0 & 0 & 0 \\ \text { Yes } & 0.16(0.07 ; & 0.19(0.11 ; & 0.13(0.04 ; & 0.20(0.11 ; \\ & 0.24) & 0.28) & 0.22) & 0.29)\end{array}$

Participation in PIM (2y)

$\begin{array}{lllll}\text { No } & 0 & 0 & 0 & 0 \\ \text { Yes } & -0.03(-0.13 ; & -0.15(-0.26 ; & 0.002(-0.10 ; & -0.15(-0.26 ; \\ & 0.08) & -0.05) & 0.11) & -0.04)\end{array}$

Crude analyses. *test for trend

Table 4 presents crude and adjusted analyses of the association between childcare attendance and child development. In the crude analyses, children who attended childcare centers at any point in life presented higher means in all the outcomes, except the motor domain. Besides that, the effect was higher for those 
who always went to childcare, compared to those who never went. In the adjusted analyses, in the model I only the category of the ones who always went to childcare presented higher means of the outcomes compare to the children who never went, except the motor domain. Also in the crude and adjusted model I, the total, cognitive and language domains presented a positive trend raise in the outcomes. The model II, which included stimulation, presented the same pattern of association than the model I, even though the association for cognitive and language was borderline. Only the total development presented a trend positive association between childcare and the outcome.

Table 4

Association between childcare attendance and early childhood development at 2 years.

\begin{tabular}{|c|c|c|c|c|c|c|}
\hline & \multicolumn{2}{|l|}{ Crude } & \multicolumn{2}{|c|}{ Model I } & \multicolumn{2}{|c|}{ Model II } \\
\hline & BETA & $(95 \% \mathrm{Cl})$ & BETA & $(95 \% \mathrm{Cl})$ & BETA & $(95 \% \mathrm{Cl})$ \\
\hline Total development & & $<0.001 *$ & & $<0.001^{\star}$ & & $0.003^{\star}$ \\
\hline Never & 0 & & 0 & & 0 & \\
\hline Some point in life & 0.08 & $(0.01 ; 0.16)$ & 0.07 & $(-0.01 ; 0.16)$ & 0.05 & $(-0.02 ; 0.13)$ \\
\hline Always & 0.21 & $(0.10 ; 0.31)$ & 0.19 & $(0.08 ; 0.31)$ & 0.17 & $(0.06 ; 0.28)$ \\
\hline Cognitive development & & $<0.001^{\star}$ & & $0.02 *$ & & $0.11 *$ \\
\hline Never & 0 & & 0 & & 0 & \\
\hline Some point in life & 0.10 & $(0.02 ; 0.18)$ & 0.03 & $(-0.04 ; 0.11)$ & 0.003 & $(-0.07 ; 0.08)$ \\
\hline Always & 0.25 & $(0.14 ; 0.35)$ & 0.13 & $(0.03 ; 0.24)$ & 0.10 & $(-0.003 ; 0.21)$ \\
\hline Motor development & & $0.21^{*}$ & & $0.25^{\star}$ & & $0.47 *$ \\
\hline Never & 0 & & 0 & & 0 & \\
\hline Some point in life & 0.02 & $(-0.05 ; 0.10)$ & 0.02 & $(-0.06 ; 0.10)$ & 0.001 & $(-0.08 ; 0.08)$ \\
\hline Always & 0.06 & $(-0.04 ; 0.17)$ & 0.07 & $(-0.04 ; 0.18)$ & 0.05 & $(-0.06 ; 0.16)$ \\
\hline Language development & & $<0.001 *$ & & $0.02^{\star}$ & & $0.14^{*}$ \\
\hline Never & 0 & & 0 & & 0 & \\
\hline Some point in life & 0.09 & $(0.02 ; 0.17)$ & 0.02 & $(-0.05 ; 0.10)$ & -0.006 & $(-0.08 ; 0.07)$ \\
\hline Always & 0.24 & $(0.14 ; 0.35)$ & 0.14 & $(0.03 ; 0.25)$ & 0.10 & $(-0.003 ; 0.21)$ \\
\hline $\begin{array}{l}\text { Crude analysis }(\mathrm{N}=3778 \\
\text { gestational age, low birth } \\
\text { variables }(\mathrm{N}=3561) ;{ }^{*} \text { Tes }\end{array}$ & $\begin{array}{l}\text { lodel } \\
\text { lodel } \\
\text { or tre }\end{array}$ & $\begin{array}{l}\text { justed for } \\
\text { maternal d }\end{array}$ & $\begin{array}{l}\text { later } \\
\text { sion }\end{array}$ & $\begin{array}{l}\text { age, family } \\
\text { =3561); Moc }\end{array}$ & $\begin{array}{l}\text { ne, } m \\
\text { Mode }\end{array}$ & $\begin{array}{l}\text { ernal education, } \\
\text { + stimulation }\end{array}$ \\
\hline
\end{tabular}

\section{Discussion}


The present study showed that the children more exposed to childcare, present better scores of total development, also in the cognitive and language domains. These results remained even after adjustment for several confounders, including parents' stimulation, which is an important influencer of the ECD.

Total development was associated with all independent variables, except for maternal age, maternal depression and child participation in PIM. The present study also shows that children of older mothers are more likely to be in center-based care, in agreement with another study (14). This may explain the association with mothers' age and total development. Although mother depression symptoms was not associated with total development, cognitive and language domains were negatively associated with this condition. Some studies show that children of depressed mothers show poorer socio-emotional and cognitive outcomes $(15,16)$, with maternal depression leading to compromised interaction patterns and reduced child stimulation. Besides, the negative association found between PIM participation and child development outcomes in this study may be due to the program focusing on vulnerable families with children at elevated risk for developmental delay (17).

In the crude analysis, any influence of childcare was positively associated with total, cognitive and language, but the motor domain. Similar results, indicating that children who went to centre-based childcare present better development are encounter in the literature $(6,14)$. After adjustment, only the children who always went to childcare had higher means in the development measures, except in the motor domain. Considering the time of exposure to the child in the center-based care, one study has shown that the early care was associated with better cognitive outcome than informal care at ages 3 , and 5 years (14). However, a systematic review about early childhood care and cognitive development has shown that the relation between early beginning and longer duration with the cognitive development it still inconsistent (6).

This association pattern remained after adjustment for child stimulation, which is one of the most important "interventions" related to the development. Several studies show that the stimulation, here presented as parents' storytelling, going to park/square and other people houses, and PIM participation, is a positive influence in the child development $(3,18)$. This indicates that the childcare exposure may be a great opportunity of stimulating development, even if the child is not stimulated at home, but if they both co-occur, the improvement appears to be better.

Childcare attendance was not associated with motor domain. This findng migh be related to the type of intervention provided in childcare centers. Previous studies have shown a positive relation between childcare and motor development, but it is not conclusive (19). It appears that only childcare center, with interventions focused on movement activities, can import motor development (20).

In Brazil, one of the aims of the National Plan of Education (NPE) is expanding the provision of early childhood education centers to achieve at least $50 \%$ of children up to three years (21). In the present study, about $2 / 3$ of boys and girls never went to childcare. This proportion is low, considering the aim of the government, but is higher than the prevalence of childcare attendance in the country (23.2\%) and in the city of Pelotas (22.0\%) (22). Despite the benefit of childcare centers for children's development, each 
child has his own individuality and particularity, which could not be fully understood since the activities in the center are organized for groups. Besides that, even though there are appropriate formation and preparation, the childcare caregivers do not have the same intimate relationship with the children as do parents or relatives and this can affect the capacity to interpret children signs and needs (23).

Some limitations of the study were the smaller sample size than the whole cohort sample, but in general, they did not differ. In addition, the information regarding to type of childcare and amount of time the children spent in them were not used. Considering the strengths, the present study used a valid measure of the ECD, have a considerable large sample size and used the information of two follow-ups of the 2015 Pelotas Birth Cohort Study to build the exposure variable. Despite that, the longitudinal characteristic of the study allows the understanding better the importance of external childcare.

\section{Conclusions}

Childcare attendance is a good strategy for improving ECD, even after adjustment for diverse characteristics, including parent's stimulation at home, and must be encouraged in this age. Only motor development not shown any association with childcare attendance. Considering that more than half of the samples never attend to childcare, it is important to advise parents about its relevance. In this sense, to improve this numbers, some intervention by the local governance, like the rise in public childcare facilities numbers and/or vacancies are suggested.

\section{List Of Abbreviations}

ECD: Early Childhood Development; NPE: National Plan of Education; PIM: Programa Infância Melhor.

\section{Declarations}

\section{Ethics approval and consent to participate}

The 2015 Pelotas Birth Cohort study was approved by the Research Ethics Committee of the School of Physical Education of Federal University of Pelotas (registration number: 26746414.5.0000.5313). The parents or legal guardians of all infants included in the cohort provided written informed consent for participation.

\section{Consent for publication}

Not applicable.

\section{Availability of data and material}

The dataset supporting of this article are available upon request to the corresponding author.

\section{Competing interests}


The authors declare that they have no competing interests.

\section{Funding}

The study used data from the 2015 Pelotas Birth Cohort study and was carried out by the Postgraduate Program in Epidemiology of the Federal University of Pelotas with the support of Brazilian Association of Public Health (ABRASCO). The 2015 Pelotas Birth Cohort was funded by the Wellcome Trust (Grant 095582/Z/11/Z). Funding was also received for specific follow-up from the Brazilian National Research Council (CNPq), Coordination for the Improvement of Higher Education Personnel (CAPES) (grant number 2207/2012) and Rio Grande do Sul State Research Support Foundation (FAPERGS). None of the funding organizations of this study influenced the study design, data collection, data analysis, data interpretation, or writing of the manuscript.

\section{Authors' contributions}

OAAL and ADB designed the present study. OAAL and ADB led the analysis. OAAL, ADB, JM, MRD and MFS contributed to results interpretation. OAAL, ADB, JM, MRD, MFS, NAN, CCD and GIM collaborated with the critical revision of the manuscript. All authors read, revised and approved the final manuscript.

\section{Acknowledgements}

Elizabeth Tunes and Glória Isabel Niño Cruz.

\section{References}

1. Nelson CA. The neurobiological bases of early intervention. Handbook of early childhood intervention. 2000;2:204-27.

2. Sameroff A. The transactional model: American Psychological Association; 2009.

3. McCoy DC, Peet ED, Ezzati M, Danaei G, Black MM, Sudfeld CR, et al. Early childhood developmental status in low-and middle-income countries: national, regional, and global prevalence estimates using predictive modeling. PLoS Medicine. 2016;13(6):e1002034.

4. Gil J, Ewerling F, Ferreira L, Barros A. Early Childhood Developmental Delay in 63 Low-and MiddleIncome Countries: Prevalence and Inequalities Estimated From National Health Surveys. Available at SSRN 3386281. 2019.

5. Black MM, Walker SP, Fernald LC, Andersen CT, DiGirolamo AM, Lu C, et al. Early childhood development coming of age: science through the life course. The Lancet. 2017;389(10064):77-90.

6. Burger K. How does early childhood care and education affect cognitive development? An international review of the effects of early interventions for children from different social backgrounds. Early childhood research quarterly. 2010;25(2):140-65. 
7. Nations U. Sustainable Development Goals 2019 [cited 201929 Oct]. Available from: https://www.un.org/sustainabledevelopment/education.

8. Hallal PC, Bertoldi AD, Domingues MR, da Silveira MF, Demarco FF, da Silva ICM, et al. Cohort profile: the 2015 Pelotas (Brazil) birth cohort study. International journal of epidemiology. 2017;47(4):1048-h.

9. Bertoldi AD, Barros FC, Hallal PR, Mielke GI, Oliveira PD, Maia MFS, et al. Trends and inequalities in maternal and child health in a Brazilian city: methodology and sociodemographic description of four population-based birth cohort studies, 1982-2015. International journal of epidemiology. 2019;48(Supplement_1):i4-i15.

10. Fernandes M, Stein A, Newton CR, Cheikh-Ismail L, Kihara M, Wulff K, et al. The INTERGROWTH-21st Project Neurodevelopment Package: a novel method for the multi-dimensional assessment of neurodevelopment in pre-school age children. PloS one. 2014;9(11):e113360.

11. Murray E, Fernandes M, Newton CR, Abubakar A, Kennedy SH, Villar J, et al. Evaluation of the INTERGROWTH-21st Neurodevelopment Assessment (INTER-NDA) in 2 year-old children. PLoS One. 2018;13(2):e0193406.

12. Cox JL, Holden JM, Sagovsky R. Detection of postnatal depression: development of the 10-item Edinburgh Postnatal Depression Scale. The British journal of psychiatry. 1987;150(6):782-6.

13. Santos IS, Matijasevich A, Tavares BF, Barros AJ, Botelho IP, Lapolli C, et al. Validation of the Edinburgh Postnatal Depression Scale (EPDS) in a sample of mothers from the 2004 Pelotas Birth Cohort Study. Cadernos de Saúde Pública. 2007;23:2577-88.

14. Côté SM, Doyle O, Petitclerc A, Timmins L. Child care in infancy and cognitive performance until middle childhood in the millennium cohort study. Child development. 2013;84(4):1191-208.

15. Bernard-Bonnin A-C, Society CP, Health M, Committee DD. Maternal depression and child development. Paediatrics \& Child Health. 2004;9(8):575-83.

16. Cummings EM, Davies PT. Maternal depression and child development. Journal of child psychology and psychiatry. 1994;35(1):73-122.

17. Schneider A, Ramires VR. Primeira Infância Melhor: uma inovação em política pública. 2007.

18. Barros AJ, Matijasevich A, Santos IS, Halpern R. Child development in a birth cohort: effect of child stimulation is stronger in less educated mothers. International Journal of Epidemiology. 2009;39(1):285-94.

19. Wick K, Leeger-Aschmann CS, Monn ND, Radtke T, Ott LV, Rebholz CE, et al. Interventions to promote fundamental movement skills in childcare and kindergarten: a systematic review and meta-analysis. Sports Medicine. 2017;47(10):2045-68.

20. Adamo KB, Wilson S, Harvey AL, Grattan KP, Naylor P-J, Temple VA, et al. Does intervening in childcare settings impact fundamental movement skill development? Medicine \& Science in Sports \& Exercise. 2016;48(5):926-32.

21. Inep M. Plano Nacional de Educação PNE 2014-2024: linha de base. Brasília: INEP. 2015. 
22. Educação PNd. Percentual da população de 0 a 3 anos que frequenta a escola/creche (Taxa de atendimento escolar) 2019 [cited 201929 Oct]. Available from: http://simec.mec.gov.br/pde/grafico_pne.php.

23. Tunes $E$, Prestes $Z$. Apontamentos sobre educação de bebês e de crianças pequenas. Teoria e Prática da Educação. 2019;22(1):32-43. 